\title{
Albumin and Furosemide versus Mannitol and Furosemide in the Treatment of Diuretic Resistant Oedema in Childhood Nephrotic Syndrome
}

\author{
SYED SAIMUL HUQUE ${ }^{1}$, MD. HABIBUR RAHMAN ${ }^{2}$, GOLAM MUIN UDDIN ${ }^{2}$, SALMA JAHAN ${ }^{1}$, AFROZA $^{3}$ \\ BEGUM $^{3}$, RANJIT RANJAN ROY ${ }^{3}$, M. MOAZZAM HOSSAIN ${ }^{2}$
}

\begin{abstract}
:
Background: To treat resistant oedema in childhood nephrotic syndrome is a therapeutic dilemma. This study was carried out to compare the efficacy of mannitol \& furosemide with that of albumin \& furosemide in the treatment of diuretic resistant oedema in childhood nephrotic syndrome.

Methodology: Forty children with "resistant oedema" due to idiopathic nephrotic syndrome at Paediatric Nephrology Department, Bangabandhu Sheikh Mujib Medical University (BSMMU) from September 2006 to April 2008 were enrolled in this descriptive cross sectional study. 'Resistant oedema' was considered based on failure to achieve therapeutic response to diuretics or a weight loss of $<1 \%$ body weight daily. All nephrotic syndrome patients with anasarca, age 1 year to 15 years of both sexes were hospitalized and were managed with fluid restriction, salt restriction and bed rest. Beside these 2 $\mathrm{mg} / \mathrm{kg} /$ day oral furosemide or combination of furosemide and spironolactone, were given for 3 days to achieve desired diuresis. Those patients who did not get response were divided into two groups (Group-A, Group- $B$ ) in consecutive fashion. The GroupA study population, was with intravenous mannitol $0.5-1 \mathrm{gm} / \mathrm{kg} /$ day in single daily dose over 1-2 hrs followed by intravenous furosemide $1 \mathrm{mg} / \mathrm{kg} /$ day for 5 days. The Group-B study population was with intravenous albumin, $0.5-1 \mathrm{gm} / \mathrm{kg} /$ day in single daily dose over 1-2 hrs followed by intravenous furosemide $1 \mathrm{mg} / \mathrm{kg} /$ day in every alternate day, total 3 doses. Efficacy of both groups of drugs was observed day to day by recording the follow-up chart.
\end{abstract}

Results: Efficacy of treatment was evaluated by measuring weight loss and increment of urine volume. Much more increment of urine volume was occurred after albuminfurosemide infusion $(1383 \pm 949.45 \mathrm{ml} v$ s $139.17 \pm 88.84 \mathrm{ml})$ than in mannitol-furosemide infusion (928.13 $\pm 359.61 \mathrm{ml} v \mathrm{vs} 151.88 \pm 67.15 \mathrm{ml})$. But the difference between the two groups was not statistically significant. Body weight was reduced $13.74 \%$ in Mannitolfurosemide group. All other parameters like abdominal girth and complications of oedema reduction were similar with albumin \& furosemide group.

Conclusion: It is concluded that response to mannitol-furosemide combination is as effective as albumin with furosemide in the treatment of diuretic resistant oedema in children with nephrotic syndrome. However, new combination is less costly and may be more useful in our society.

Key words: Albumin, Mannitol, Furosemide, Diuretic resistant oedema,

1. Assistant Professor, Department of Paediatric Nephrology, BSMMU

2. Professor, Department of Paediatric Nephrology, BSMMU

3. Associate Professor, Department of Paediatric Nephrology, BSMMU

Correspondence: Dr. Syed Saimul Huque, Assistant Professor, Department of Paediatric Nephrology, BSMMU. E-mail saimul264@yahoo.com

\section{Introduction}

Oedema is the chief clinical manifestation of nephrotic syndrome, which may vary from mild periorbital puffiness to anasarca. When nephrotic range of proteinuria ( $>1 \mathrm{gm} / \mathrm{m}^{2} /$ day or $>40 \mathrm{mg} / \mathrm{m}^{2} / \mathrm{hr}$ ) persists and serum albumin level declines to $<25 \mathrm{gm} / \mathrm{L}$, fluid 
retention and oedema usually starts to develop ${ }^{1,2,3,4}$. It is clinically apparent when interstitial fluid is expanded by an amount greater than or equal to $5 \%$ of body weight ${ }^{5,6}$.

Children with steroid unresponsive childhood nephrotic syndrome usually and frequently become infected due to loss of integrity of skin as a result of massive ascities. It can exacerbate preexisting hypertension and may cause respiratory embarrassment. Sometimes oedema of intestinal wall may result in diarrhoea. Children may have restricted activity and low self-esteem.

In most of the cases, patients with nephrotic syndrome present with mild periorbital puffiness or pedal oedema. So it does not require any diuretics. Patients showing moderate to severe oedema with symptomatic fluid overload need specific treatment. General measures to control oedema include salt restriction, fluid restriction and judicious administration of furosemide. Additional use of thiazide \& potassium sparing diuretics can be used along with this regime $7,8,9$. If these fail, then intravenous albumin with furosemide is usually needed. This treatment is not without risks, as in many nephrotic patients the intravascular volume is normal or increased rather than low, so intravenous albumin infusion is a bad practice $\&$ can be dangerous ${ }^{3}$. Moreover, we know that albumin is made from human plasma, so chance of transfer of infectious diseases, especially viral infections are more marked.

Aggressive therapy for oedema is required in less than $10 \%$ patients ${ }^{10}$. In all cases, it is important to establish a goal, usually a weight loss of $1 \%$ body weight daily. If this is not achieved then it is considered inadequate response ${ }^{10}$. Diuretic resistance in the oedematous patient has been defined as a clinical state in which diuretic response is diminished or lost before the therapeutic goal of relief from oedema has been reached ${ }^{11}$. Oedematous patients may exhibit apparent resistance to oral diuretics due to reduced intestinal drug absorption. Moreover increased intraluminal protein binding of the diuretic occurs in nephrotic syndrome, so that fewer molecules of the diuretic are free to interact with and inhibit the $\mathrm{Na}^{+}$$2 \mathrm{Cl}^{-}-\mathrm{K}^{+}$cotransport system, which is located in the luminal membrane of the thick ascending loop of Henle 12. Reduced secretion of diuretic into the tubule lumen due to renal hypoperfusion and diminished glomerular filtration rate may also exacerbate diuretic resistance ${ }^{13}$. If these above mentioned problems can be overcome, rapid diuresis of oedema may be achieved in diuretic resistant oedema.

Mannitol has several potential advantages in patients with nephrotic syndrome. The diuretic activity of mannitol acts throughout the nephron ${ }^{14,15}$. Moreover, mannitol is a safe and inexpensive treatment that allows for use more than once daily if required. Mannitol may have the added advantage of a glomerular vasodilator action which results in increased glomerular hydrostatic pressure and glomerular filtration rate (GFR). Moreover, the osmotic effects of mannitol will lower the intraluminal albumin concentration and reduce the binding of furosemide to albumin, thereby enhancing its activity ${ }^{14}$. So mannitol would be of great value in developing countries where the availability and purity of $20 \%$ albumin is limited and also costly.

\section{Methodology}

Forty consecutive patients whose parents agreed to participate (by written informed consent) and who met the inclusion criteria at Paediatric Nephrology Department, Bangabandhu Sheikh Mujib Medical University (BSMMU) from September 2006 to April 2008 were enrolled in this descriptive cross sectional study. Confirmation of the diagnosis of initial attack nephrotic syndrome or relapse nephrotic syndrome were based on (1) history (2) physical examination (3) relevant investigations that includes- urine routine examination and culture sensitivity, 24hrs urinary total protein or spot urinary protein creatinine ratio, serum albumin, serum cholesterol, complete blood count, serum creatinine, serum electrolytes, X-ray chest. Fluid overload was observed through history and physical examinations. All the patients were hospitalized and were managed with fluid restriction (400 ml/ $\mathrm{m}^{2}+$ previous day output), salt restriction (1$2 \mathrm{meq} / \mathrm{kg} / \mathrm{day}$ ) \& bed rest. Beside these, $2 \mathrm{mg} / \mathrm{kg} /$ day oral furosemide or combination of furosemide \& spironolactone was given for 3 days to achieve desired diuresis or more than $1 \%$ weight loss per day in anasarca or symptomatic fluid overload patient after assessing volume status. If therapeutic goal of relief from oedema had not been reached, then we considered these patients as 'diuretic resistant" and divided into two groups (Group-A, Group-B) in consecutive fashion. The Group-A study population, was with intravenous mannitol 0.5-1 gm/ $/ \mathrm{kg} /$ day in single daily dose over 1-2 hrs followed by intravenous furosemide $1 \mathrm{mg} / \mathrm{kg} /$ day for 5 days. The Group-B study population was with intravenous albumin, $0.5-1 \mathrm{gm} /$ 
$\mathrm{kg} /$ day in single daily dose over 1-2 hrs followed by intravenous furosemide $1 \mathrm{mg} / \mathrm{kg} /$ day in every alternate day, total of 3 doses. Infusions of albumin are preferably given on alternate day to get the significant diuresis but without any major side effect. The study was approved by the Institutional Ethics Board.

Efficacy of both groups of drugs was observed day to day by recording daily pulse, blood pressure measurement, weight chart, abdominal girth (at the level of umbilicus), intake-output chart, dependent oedema, scrotal swelling. The patient's urine was collected over $24 \mathrm{hrs}$ from 8 a.m. to 8 a.m. of the next day. Beside these, serum electrolytes and serum creatinine were observed on the sixth day after these drugs therapy to see any imbalance or complications.

Data were reported as mean \pm standard deviation (SD). Numerical data were analyzed using paired test (two tailed) and the level of statistical significance was set at $P<0.05$.

\section{Results}

Forty patients both male and female were included in this study. The mean age was 75.8 months and the age range was 24-144 months in Group-A and in Group- $B$, the mean age was 59.1 months with the age range was 18-140 months. Over all male-female ratio was 2.08:1. Efficacy of treatment was evaluated as weight loss and increment of urine volume. Much more increment of urine volume was occurred after albumin-furosemide infusion $(1383 \pm 949.45$ vs $139.17 \pm 88.84$ ) than in mannitol-furosemide infusion $(928.13 \pm 359.61$ vs $151.88 \pm 67.15)$. But the difference between the two groups was not statistically significant (Table I). Body weight was reduced by $13.74 \%$ in Mannitol-furosemide group (Table II). All other parameters like abdominal girth and complications of oedema reduction were similar or better with mannitol with furosemide.

Table-I

Age distribution of the patients of both the group $(n=40)$

\begin{tabular}{|c|c|c|c|}
\hline $\begin{array}{l}\text { Age } \\
\text { (month) }\end{array}$ & $\begin{array}{c}\text { Group A }(\mathrm{n}=16) \\
\text { (Mannitol }+ \\
\text { Furosemide) }\end{array}$ & $\begin{array}{c}\text { Group B }(\mathrm{n}=24) \\
\text { (Albumin }+ \\
\text { Furosemide) }\end{array}$ & $\begin{array}{c}\mathrm{p} \\
\text { value }\end{array}$ \\
\hline d"25 & $1(6.3)$ & $3(12.5)$ & \\
\hline $26-50$ & $2(12.5)$ & $6(25.0)^{\S}$ & \\
\hline $51-75$ & $7(43.8)$ & $9(37.5)$ & \\
\hline $76-100$ & $2(12.5)$ & $2(8.3)$ & \\
\hline 101 to above & $4(25.0)$ & $4(16.7)$ & \\
\hline Total & $16(100.0)$ & $24(100.0)$ & \\
\hline $\begin{array}{l}\text { Mean } \pm S D \\
\text { (range) }\end{array}$ & $\begin{array}{c}75.8 \pm 39.23 \\
(24-144)\end{array}$ & $\begin{array}{l}59.1 \pm 32.8 \\
(18-140) \text { §§ }\end{array}$ & $0.152^{*}$ \\
\hline
\end{tabular}

*Unpaired test was done to measure the level of significance.
Table-II

Different physical and biochemical parameters before and after mannitol therapy $(n=16)$.

\begin{tabular}{lccc}
\hline & $\begin{array}{c}\text { Before } \\
\text { therapy }\end{array}$ & $\begin{array}{c}\text { After therapy } \\
\text { (day 6) }\end{array}$ & $\begin{array}{c}\mathrm{p} \\
\text { value* }^{*}\end{array}$ \\
\hline $\begin{array}{l}\text { Pulse } \\
\text { (beat/min) }\end{array}$ & $90.88 \pm 10.95$ & $96.38 \pm 11.25$ & 0.021 \\
$\begin{array}{l}\text { Systolic BP } \\
\text { (mm of Hg) }\end{array}$ & $104.4 \pm 13.6$ & $108.4 \pm 13.4$ & 0.386 \\
$\begin{array}{l}\text { Diastolic BP } \\
\text { (mm of Hg) }\end{array}$ & $68.1 \pm 8.3$ & $71.6 \pm 9.9$ & 0.278 \\
$\begin{array}{l}\text { Respiratory rate } \\
\text { (beat/min) }\end{array}$ & $29.1 \pm 5.8$ & $24.1 \pm 1.7$ & 0.002 \\
$\begin{array}{l}\text { Abdominal girth } \\
\text { (cm) }\end{array}$ & $71.75 \pm 5.84$ & $65.5 \pm 8.26$ & 0.019 \\
$\begin{array}{l}\text { Intake (ml/day) } \\
\text { Output (ml/day) }\end{array}$ & $\begin{array}{l} \\
151.88 \pm 67.15928 .13 \pm 359.61\end{array}$ & 0.001 \\
$\begin{array}{l}\text { Body weight (kg) } \\
25.19 \pm 8.67\end{array}$ & $21.97 \pm 8.56$ & 0.299 \\
$\begin{array}{l}\text { Serum creatinine } \\
\text { (mg/dl) }\end{array}$ & $0.61 \pm 0.1$ & $0.52 \pm 0.17$ & 0.078 \\
$\begin{array}{l}\text { S. sodium } \\
\text { (mmol/L) }\end{array}$ & $137.5 \pm 3.9$ & $137.6 \pm 5.11$ & 0.860 \\
\hline
\end{tabular}

Table-III

Different physical and biochemical parameters before and after albumin therapy $(n=24)$.

\begin{tabular}{lccc}
\hline & $\begin{array}{c}\text { Before } \\
\text { therapy }\end{array}$ & $\begin{array}{c}\text { After therapy } \\
\text { (day 6) }\end{array}$ & $\begin{array}{c}\mathrm{p} \\
\text { value }^{*}\end{array}$ \\
\hline Pulse(beat/min) & $97.83 \pm 15.66$ & $102.8 \pm 10.0$ & 0.165 \\
$\begin{array}{l}\text { Systolic BP } \\
\text { (mm of Hg) }\end{array}$ & $100.2 \pm 12.3$ & $104.6 \pm 11.7$ & 0.112 \\
$\begin{array}{l}\text { Diastolic BP } \\
\text { (mm of Hg) }\end{array}$ & $63.8 \pm 9.2$ & $68.8 \pm 9.5$ & 0.015 \\
$\begin{array}{l}\text { Respiratory rate } \\
\text { (beat/min) }\end{array}$ & $30.7 \pm 9.1$ & $24.7 \pm 5.6$ & 0.011 \\
$\begin{array}{l}\text { Abdominal girth } \\
\text { (cm) }\end{array}$ & $63.33 \pm 8.57$ & $58.38 \pm 7.6$ & 0.039 \\
$\begin{array}{l}\text { Intake } \\
\text { (ml/day) }\end{array}$ & $365.42 \pm 155.93$ & $902.08 \pm 582.63$ & 0.001 \\
$\begin{array}{l}\text { Output } \\
\text { (ml/day) }\end{array}$ & $139.17 \pm 88.84$ & $1383.33 \pm 949.45$ & 0.001 \\
$\begin{array}{l}\text { Body weight } \\
\text { (kg) }\end{array}$ & $20.02 \pm 7.61 \S$ & $18.0 \pm 7.18$ & 0.349 \\
$\begin{array}{l}\text { Serum } \\
\text { creatinine (mg/dl) }\end{array}$ & $0.53 \pm 0.16$ & $0.76 \pm 0.17$ & 0.001 \\
$\begin{array}{l}\text { S. sodium } \\
\text { (mmol/l) }\end{array}$ & $136.04 \pm 3.7$ & $140.1 \pm 3.3$ & 0.008 \\
\hline
\end{tabular}


Table-IV

Changes in body weight and abdominal girth of the patient of both group after therapy $(n=40)$

\begin{tabular}{lcc}
\hline $\begin{array}{l}\text { Age } \\
\text { (month) }\end{array}$ & $\begin{array}{c}\text { Group A }(\mathrm{n}=16) \\
\text { (Mannitol }+ \\
\text { Furosemide) }\end{array}$ & $\begin{array}{c}\text { Group B }(\mathrm{n}=24) \\
\text { (Albumin }+ \\
\text { Furosemide) }\end{array}$ \\
\hline Before therapy & $25.19 \pm 8.67$ & $21.43 \pm 4.70$ \\
After therapy & $21.97 \pm 8.56$ & $18.70 \pm 4.42$ \\
$\%$ of decline & $13.74 \pm 7.46$ & $12.87 \pm 5.10$ \\
Abdominal girth $(\mathrm{cm})$ & & \\
Before therapy & $71.75 \pm 5.84$ & $63.33 \pm 8.57$ \\
After therapy & $65.5 \pm 8.26$ & $58.38 \pm 7.6$ \\
\% of decline & $8.76 \pm 8.32$ & $7.23 \pm 9.09$ \\
\hline
\end{tabular}

*Unpaired t-test was done to measure the level of significance.

Table- V

Comparison of changes in intake \& output in both group $(n=40)$

\begin{tabular}{lccc}
\hline $\begin{array}{l}\text { Age } \\
\text { (month) }\end{array}$ & $\begin{array}{c}\text { Group A }(\mathrm{n}=16) \\
\text { (Mannitol }+ \\
\text { Furosemide) }\end{array}$ & $\begin{array}{c}\text { Group B }(\mathrm{n}=24) \\
\text { (Albumin }+ \\
\text { Furosemide) }\end{array}$ & $\begin{array}{c}\mathrm{p} \\
\text { value }\end{array}$ \\
\hline $\begin{array}{l}\text { Intake (ml) } \\
\text { Before therapy }\end{array}$ & $\begin{array}{c}437.5 \pm 111.8 \\
365.42 \pm 155.93^{\S}\end{array}$ & 0.119 \\
$\begin{array}{l}\text { After therapy } \\
\text { (day 6) }\end{array}$ & $612.5 \pm 181.19$ & $902.08 \pm 582.63$ & 0.62 \\
$\begin{array}{l}\text { Output (ml) } \\
\text { Before therapy }\end{array}$ & $151.88 \pm 67.15$ & $139.17 \pm 88.84$ & 0.63 \\
$\begin{array}{l}\text { After therapy } \\
\text { (day 6) }\end{array}$ & $928.13 \pm 359.611383 .33 \pm 949.45$ & 0.076 \\
\hline
\end{tabular}

*Unpaired t-test was done to measure the level of significance.

\section{Discussion}

In this study, no significant increase in the volume of urine and weight loss was observed in patients with diuretic resistant oedema of nephrotic syndrome when mannitol was infused along with furosemide administration as compared with administration of albumin and furosemide. We speculate that albumin and mannitol might expand plasma volume, which might therefore have improved the diuretic action of furosemide.

Fliser et al. (1999) in a double blind placebo controlled study, reported that co-administration of human albumin potentiates the action of furosemide in patients with nephrotic syndrome, but only modestly ${ }^{15}$. On the other hand, mannitol is an osmotic agent that is freely filterable at the glomerular level but it is not reabsorbed by the renal tubules. By virtue of its primary site and mechanism of action, mannitol has a high diuretic potential and can markedly increase fluid flow rate in all nephron segments including the proximal tubule. In order to prevent a compensatory increase in ion reabsorption in the loop of Henle, mannitol is usually administered in combination with a loop diuretic. Moreover, the dilution of the tubular fluid through the osmotic effects of mannitol in the proximal tubule will lower the intraluminal albumin concentration and therefore reduce the binding of furosemide to albumin, enhancing its activity. The response to intravenous albumin in this situation is unpredictable. Though the use of albumin after binding with furosemide can enhance filtration but it cannot reduce the intraluminal binding of furosemide to albumin. So less amount of free furosemide is found to inhibit the the $\mathrm{Na}^{+}-2 \mathrm{Cl}^{-}-\mathrm{K}^{+}$co-transport system ${ }^{14}$. We got 4 out of 24 generalized body swelling patients, who were treated with albumin and furosemide. They did not improve significantly, probably due to this reason.

Lewis MA, Awan A (1990) found 10-30\% weight reduction by intravenous infusion of mannitol for one week $^{16}$. This study found significant (13.74\%) weight reduction after five days of mannitol infusion along with furosemide. Along with weight reduction, significant abdominal girth reduction was also observed in Mannitol group, which helps to improve patient's well-being.

Though after getting albumin-furosemide combination therapy, massive diuresis occurred but was not significant as compared to mannitol-furosemide combination therapy. Furthermore, significant symptomatic improvement occurred in both groups of patients in the form of abdominal girth reduction, disappearance of scrotal/labial swelling and respiratory distress.

In these series, we observed no side effects in both groups. It is noteworthy that in our patients, only diastolic blood pressure was increased significantly in albumin-furosemide group, but did not cross the normal range. However no such change was observed in Mannitol group. As the transit time is short and the diuresis is prompt, mannitol is relatively safe to treat diuretic resistant nephrotic oedema, without change of blood pressure.

Serum sodium and Serum creatinine level were minimally affected by both interventions. Sodium was increased after albumin therapy which may be due to presence of sodium in albumin or tubular resistance to atrial natriuretic peptide in nephrotic syndrome 17,18. But this increase was not statistically significant. 
Creatinine was low in Mannitol group but high in Albumin group, may be due to increase in protein catabolism of albumin. However, this change was within normal range. Yoshida et al. showed that albumin overload in vivo and in vitro promotes podocyte injury and may exacerbate chronic kidney disease ${ }^{19}$.

As to the clinical management of patients with diuretic resistant nephrotic oedema, it emerges from this study that it is more sensible to infuse mannitol-furosemide combination instead of albumin-furosemide combination therapy. Our findings lend credence to numerous uncontrolled clinical observations that coadministration of albumin increases the diuretic potency of furosemide, but the same is also true for mannitol-furosemide co-administration. A potential drawback of albumin-furosemide approach is the short duration of albumin's action, besides its cost. Albumin is completely lost in urine over $48-72$ hours ${ }^{10,16,20}$. So mannitol-furosemide combination will prove invaluable in the management of diuretic resistant oedema without hypovolaemia in nephrotic syndrome.

There are several limitations in our study. Firstly, we did not perform any laboratory test to evaluate the plasma volume status of the patients. It was therefore not possible to assess any sequential changes in plasma volume after albumin and mannitol infusion. Secondly, had the findings of the renal pathology been more uniform, the experiment would have produced more consistent data. However, it was not practically easy to recruit patients with nephrotic syndrome with homogenous pathology. Thirdly, sample size is small.

Inspite of these above limitations, we are of an opinion that these limitations had little adverse effects on the reliability of our data.

\section{Conclusion}

It has been concluded from this study that though both mannitol-furosemide and albumin-furosemide are more or less equally effective for the treatment of diuretic resistant oedema in childhood nephrotic syndrome, but for considering the higher cost of albumin-furosemide combination, mannitol-furosemide combination may be more useful in countries like our socio-economic background.

\section{References}

1. Hogg RJ, Portman RJ, Milliner D, Lemley KV, Eddy A, Ingel finger J. Evaluation and management of proteinuria and nephrotic syndrome in children: recommendations from a paediatric nephrology panel established at the National Kidney Foundation conference on proteinuria, albuminuria, risk, assessment, detection and elimination (PARADE). Pediatrics 2000;105:1242-49.

2. Bergstein JM. Nephrotic syndrome. In: Kleigman RM, Stanton BF, Schor NF, St. Geme JW, Behrman RE, editors. Nelson Textbook of Pediatrics, 19th ed. Philadelphia:W B Saunders company;2011: 1801-03.

3. Indian Pediatric Nephrology Group, Indian Academy of Pediatrics. Consensus statement on management of steroid sensitive nephrotic syndrome. Indian Pediatr 2001;38:975-86.

4. ISKDC. The primary nephrotic syndrome in children. Identification of patients with minimal change nephrotic syndrome from initial response to prednisolone. J Pediatr 1981;98:561-64.

5. Haycock GB. Sodium \& body fluids. In: Barratt TM, Avner ED, Harmon WE, editors. Pediatric Nephrology. $4^{\text {th }}$ ed. Maryland:Wolters Kluwer Company; 1999:147-49.

6. Trachtman H. Sodium and Water. In: Avner ED, Harmon WE, Niaudet $P$, Yoshikawa N, editors. Pediatric Nephrology. 6th ed. Maryland:Wolters Kluwer Company; 2009:159-82.

7. Niaudet P. Steroid-sensitive idiopathic nephrotic syndrome. In: Avner ED, Harmon WE, Niaudet $P$, editors. Pediatric Nephrology, $5^{\text {th }}$ ed. Philadelphia: Lippincott Williams \& Wilkins; 2004:543-56.

8. Roth KS, Amaker BH, Chan JC. Nephrotic Syndrome: Pathogenesis and Management. Pediatrics 2002;23:237-48.

9. Gbadegesin R and Smoyer WE. Nephrotic Syndrome. In: Geary DF, Schaefer F, editors. Comprehensive Pediatric Nephrology, $1^{\text {st }}$ ed. Philadelphia:MOSBY Elsevier;2008:205-16.

10. Vasudevan A, Mantan M, BaggaA. Management of Edema in Nephrotic Syndrome. Indian Pediatrics 2004;41:787-95.

11. Kramer BK, Schweda F, Riegger GAJ. Diuretic Treatment and Diuretic Resistance in Heart Failure. Am J Med 1999;106:90-6.

12. Ellison $\mathrm{DH}$. The physiologic basis of diuretic synergism: its role in treating diuretic resistance. Ann Intern Med 1991;14:886-94. 
13. Harris RC, Ismail N. Extrarenal complications of the nephrotic syndrome. Am J Kidney Dis 1994; 23:477-97.

14. Brater DC. Resistance to diuresis: emphasis on a pharmacological perspective. Drugs 1981;22: 477-94.

15. Fliser D, Zurbruggen I, Mutschler E, Bischoff I, Nussberger J, Franek E et al. Coadministration of albumin and furosemide in patients with the nephrotic syndrome. Kidney International 1999; 55: 629-34.

16. Lewis MA, Awan A. Mannitol and frusemide in the treatment of diuretic resistant oedema in nephrotic syndrome. Arch. Dis. Child 1999; 80:184-85.
17. McBryde KD, Kershaw DB, Smoyer WE. Pediatric Steroid-Resistant Nephrotic Syndrome. Curr Probl Pediatr 2001;31:275-307.

18. Yoshida S, Nagase M, Shibata S, Fujita T. Podocyte injury induced by albumin overload in vivo and in vitro: Involvement of TGF-Beta and p38 MAPK. Nephron Exp Nephrol 2008;108: 57-68.

19. Bagga A, Srivastava RN. Nephrotic Syndrome. In: Srivastava RN, Bagga A, editors. Pediatric Nephrology. $4^{\text {th }}$ edn. New Delhi: Jaypee; 2005:114-36.

20. Seely JF, Dirks JH. 'Diuretic site of action', Kidney International 1977;11:1-8. 